Article

\title{
Highly Insulated Wall Systems with Exterior Insulation of Polyisocyanurate under Different Facer Materials: Material Characterization and Long-Term Hygrothermal Performance Assessment
}

\author{
Emishaw Iffa ${ }^{1, *}$, Fitsum Tariku ${ }^{2}$ and Wendy Ying Simpson ${ }^{2}$ \\ 1 Oak Ridge National Laboratory, Building Envelope \& Urban Systems Research, Oak Ridge, TN 37831, USA \\ 2 British Columbia Institute of Technology, BCIT Building Science Centre of Excellence, \\ Burnaby, BC V5G3H2, Canada; fitsum_tariku@bcit.ca (F.T.); wendy_simpson@bcit.ca (W.Y.S.) \\ * Correspondence: iffaed@ornl.gov; Tel.: +865-3410-470
}

Received: 28 June 2020; Accepted: 24 July 2020; Published: 30 July 2020

\begin{abstract}
The application of exterior insulation in both new construction and retrofits is a common practice to enhance the energy efficiency of buildings. In addition to increased thermal performance, the rigid insulation can serve to keep the sheathing board warm and serve as a water-resistive barrier to keep moisture-related problems due to condensation and wind-driven rain. Polyisocyanurate (PIR) rigid boards have a higher thermal resistance in comparison to other commonly used exterior insulation boards. However, because of its perceived lower permeance, its use as exterior insulation is not very common. In this study, the hygrothermal property of PIR boards with different facer types and thicknesses is characterized. The material data obtained through experimental test and extrapolation is used in a long term hygrothermal performance assessment of a wood frame wall with PIR boards as exterior insulation. Results show that PIR with no facer has the smallest accumulated moisture on the sheathing board in comparison to other insulation boards. Walls with a bigger thickness of exterior insulation perform better when no vapor barrier is used. The PIR exterior insulation supports the moisture control strategy well in colder climates in perfect wall scenarios, where there is no air leakage and moisture intrusion. In cases where there is trapped moisture, the sheathing board has a higher moisture content with PIR boards with both aluminum or fiberglass type facers. An innovative facer material development for PIR boards can help efforts targeting improved energy-efficient and durable wall systems.
\end{abstract}

Keywords: drying and wetting; hygrothermal performance; Polyisocyanurate board; moisture content; thermal performance; vapor permeability

This manuscript has been authored in part by UT-Battelle, LLC, under contract DE-AC05-00OR22725 with the US Department of Energy (DOE). The US government retains and the publisher, by accepting the article for publication, acknowledges that the US government retains a nonexclusive, paid-up, irrevocable, worldwide license to publish or reproduce the published form of this manuscript, or allow others to do so, for US government purposes. DOE will provide public access to these results of federally sponsored research in accordance with the DOE Public Access Plan (http://energy.gov/downloads/doe-public-access-plan).

\section{Introduction}

The ever-increasing demand from building codes for improved energy efficiency and society's increasing awareness of environmental sustainability is driving the building construction and manufacturing industries to develop innovative solutions for durable, high-performance buildings. It is 
well documented that the application of exterior insulation increases the overall thermal performance of new construction and retrofits [1-5]. While studying the thermal performance of a building envelope, the moisture durability needs proper consideration as well [6,7] The moisture control performance requires additional investigation and researchers are examining the effects of rigid insulation on the durability of wall systems incorporating innovative materials and construction practices [8-14].

Among the commonly used insulation materials, Polyisocyanurate (PIR) is known for its higher R-value and consequently providing an increased energy efficiency when it is compared with most of the other foam-based insulation materials [15]. However, the building industry considers PIR as impermeable or semi-permeable, and its application as exterior insulation is limited. Regarding material characterization and hygrothermal performance assessment, relatively smaller research studies are reported in comparison to the thermal performance of exterior insulation.

Burch and Desjarlais conducted a water vapor measurement test for PIR core and facer [16]. Their measurement shows that the glass-mat facers permeance varies from $600 \mathrm{ng} / \mathrm{sm} 2 . P a(10$ perm $)$ to $2800 \mathrm{ng} / \mathrm{sm} 2 . P a$ (49 perm). A study on advanced material preparation and characterization of PIR foams is an active research topic. Kosmela et al. have found that the addition of up to $30 \%$ by weight of bio-polyol, instead of foams prepared solely with a petrochemical polyol, have increased the reactivity of the polyol mixture in rigid Polyurethane-Polyisocyanurate(PUR-PIR) foams, which in turn has enhanced the thermal performance of the rigid foam [17]. Borowiciz et al. have also found that PIR foams modified with bio-polyol based on mustard seed oil have lowered the thermal conductivity and water absorption [18]. Berardi and Madzarevic analyzed the aging behavior and tested the blowing agent concentration of a PIR foam. A decrease in $11 \%$ and $85 \%$ of a blowing agent is measured from the aged PIR foams [19].

The closed cells created during PIR manufacturing are filled with the vaporized blowing agent during the foaming reaction [20]. To keep the blowing agent from migrating out and in return affecting the R-value of the PIR foam, different types of facers are used during PIR production [20-23]. Mackaveckas et al. reported on the influence of different PIR facings on thermal performance. Their findings show a significant heat loss in PIR insulation boards with aluminum facing at wall corners [24].

The main purpose of this study is to investigate the long-term hygrothermal performance of wall systems with PIR exterior insulation. To study the optimal use of the PIR insulation board, the thickness and type of facer materials were varied and their performance under different scenarios: varying moisture loads, vapor barrier applications, and different climates were investigated. Their performance was compared with another exterior rigid insulation board, extruded polystyrene (XPS).

The material characterization for the PIR took place at BCIT's Building Science Centre of excellence (BSCE). The measured thermal and hygrothermal material properties include density, thermal conductivity, heat capacity, sorption isotherm, vapor permeability, water absorption coefficient, and porosity. The next sections of this paper discuss the experimental test, the simulation setup, results obtained, and the conclusions based on experiment and simulation results.

\section{Hygrothermal Property Characterization of PIR Foam with Different Facers}

To study the long-term performance of hygrothermal simulation performance of PIR as an exterior insulation under different climates, a hygrothermal material property characterization of three types of PIR products is conducted: fiberglass-faced PIR, PIR with aluminum facer and an unfaced PIR insulation. A series of laboratory measurements are carried out to characterize the hygrothermal properties of a rigid PIR insulation board with different facing materials. The hygrothermal properties measured are density, thermal conductivity, specific heat capacity, sorption isotherm, water vapor permeability, water absorption coefficient, and porosity. Measurements are conducted in accordance with the ASTM Standards [25-28]. The measurement procedures, standards used and material characterization results are shown in the section below. 
The PIR hygrothermal property characterization under different facer materials for PIR of thickness $12.7 \mathrm{~mm}$ (0.5 in.), $25.4 \mathrm{~mm}$ (1 in.) and $38.1 \mathrm{~mm}(1.5 \mathrm{in}$.) are measured through a laboratory test. The obtained properties are extrapolated for other thickness sizes. The measured hygrothermal properties of PIR core insulation, PIR with fiberglass facer, and PIR with foil-faced PIR insulation are presented below.

The density is determined from physical dimensions and oven-dry mass measurements of six specimens for all three PIR samples, as shown in Table 1.

Table 1. Density measurement of Polyisocyanurate (PIR) board.

\begin{tabular}{|c|c|c|c|}
\hline PIR Facer Type & $\begin{array}{l}\text { Nominal Thickness mm } \\
\text { (in.) }\end{array}$ & $\begin{array}{l}\text { Actual Thickness mm } \\
\text { (in.) }\end{array}$ & Density $\mathrm{Kg} / \mathrm{m}^{3}$ \\
\hline \multirow{2}{*}{ Fiberglass facer } & $25.4(1)$ & $23.9 \mathrm{~mm}(15 / 16)$ & $55.14 \pm 0.42$ \\
\hline & $12.7(0.5)$ & $12.2(0.48)$ & $104.07 \pm 6.33$ \\
\hline Aluminum facer & $38.1(1.5)$ & 36.7 mm (1-7/16) & $34.3 \pm 0.51$ \\
\hline No facer core board & $38.1(1.5)$ & 36.7 mm (1-7/16) & $27.86 \pm 0.48$ \\
\hline
\end{tabular}

The thermal conductivity of the PIR core board and with foil and fiberglass facers is carried out according to ASTM Standard C518: "Standard Test Method for Steady-State Thermal Transmission Properties by Means of the Heat Flow Meter Apparatus "using four $-30 \mathrm{~cm} \times 30 \mathrm{~cm}$ specimens (average thickness $24.86 \mathrm{~mm}$ ). The measurements are done at a temperature difference of $20^{\circ} \mathrm{C}(68$ ${ }^{\circ} \mathrm{F}$ ) and a mean temperature of $24^{\circ} \mathrm{C}\left(75.2^{\circ} \mathrm{F}\right)$. Table 2 shows the average thermal conductivity and resistance values of the four PIR board samples for all types of facers. In addition, the maximum and the minimum measured values are also presented in the table.

Table 2. Thermal conductivity of PIR board.

\begin{tabular}{ccccccc}
\hline Facer Type & $\begin{array}{c}\text { Specimen } \\
\text { Thickness } \\
\mathbf{m m}\end{array}$ & $\begin{array}{c}\text { Mean } \\
\text { Temperature } \\
{ }^{\circ} \mathbf{C}\end{array}$ & $\begin{array}{c}\text { Hot Plate } \\
\text { Temperature } \\
{ }^{\circ} \mathbf{C}\end{array}$ & $\begin{array}{c}\text { Cold Plate } \\
\text { Temperature } \\
{ }^{\circ} \mathbf{C}\end{array}$ & $\begin{array}{c}\text { Thermal } \\
\text { Conductivity } \\
\mathbf{W} /(\mathbf{m} \cdot \mathbf{K})\end{array}$ & $\begin{array}{c}\text { Thermal } \\
\text { Resistance } \\
\mathbf{m}^{2} \cdot \mathbf{K} / \mathbf{W}\end{array}$ \\
\hline Fiberglass & $24.12 \pm 0.04$ & $24.00 \pm 0.03$ & $34.01 \pm 0.04$ & $14.01 \pm 0.04$ & $0.026 \pm 0.0007$ & $0.944 \pm 0.031$ \\
\hline Aluminum facer & $24.98 \pm 0.02$ & $24.02 \pm 0.00$ & $34.02 \pm 0.00$ & $14.02 \pm 0.00$ & $0.024 \pm 0.0008$ & $1.072 \pm 0.038$ \\
\hline No facer & $24.86 \pm 0.02$ & $23.95 \pm 0.05$ & $33.96 \pm 0.05$ & $13.95 \pm 0.05$ & $0.023 \pm 0.0008$ & $1.076 \pm 0.047$ \\
\hline
\end{tabular}

The heat capacity of the PIR for the three samples is determined using a LaserComp Fox heat flow meter (TA instruments, New Castle, DE, USA) and WinTherm32 software (TA instruments, New Castle, DE, USA) for analysis and determination of transient heat transfer through the specimens. Based on four samples measurements, both volumetric heat capacity and specific heat capacity are measured for all three types of PIR with different facers. Table 3 shows the average volumetric and heat capacity values of PIR boards.

Table 3. Heat capacity of PIR board.

\begin{tabular}{ccc}
\hline PIR Facer & $\begin{array}{c}\text { Volumetric Heat Capacity } \\
\mathbf{J} /\left(\mathbf{m}^{3} \cdot \mathbf{K}\right)\end{array}$ & $\begin{array}{c}\text { Specific Heat Capacity } \\
\mathbf{J} / \mathbf{k g} \cdot \mathbf{K})\end{array}$ \\
\hline Fiberglass facer & $62943 \pm 1083$ & $1144 \pm 23$ \\
\hline Aluminum facer & $49357 \pm 1058$ & $1439 \pm 31$ \\
\hline No facer & $38090 \pm 944$ & $1257 \pm 14$ \\
\hline
\end{tabular}

Sorption Isotherm: PIR boards with fiberglass facer and no facer are used under this study. Because of its low permeability, the aluminum-faced PIR board is not investigated for its hygrothermal 
property characterization. The equilibrium moisture contents at 50\%, 70\%, 80\%, 90\% and 95\% relative humidity $(\mathrm{RH})$ conditions and saturation moisture content in 100\% RH are determined according to ASTM Standard C1498: "Standard Test Method for Hygroscopic Sorption Isotherms of Building Materials". For each test point, three specimens with dimensions of $100 \mathrm{~mm} \times 100 \mathrm{~mm}$ with a thickness of $24 \mathrm{~mm}$ are used. The measurements are carried out in controlled climatic chambers that are maintained at a constant temperature of $23{ }^{\circ} \mathrm{C}$ and the desired relative humidity set point. A water immersion test is used to determine the capillary saturation moisture contents of the samples. Table 4 shows the measured equilibrium moisture contents of PIR board specimens at different relative humidity.

Table 4. Equilibrium moisture contents of PIR board samples.

\begin{tabular}{ccc}
\hline \multirow{2}{*}{$\mathbf{R H}, \boldsymbol{c}$} & \multicolumn{2}{c}{ Moisture Content, $\mathbf{~ k g} / \mathbf{m}^{\mathbf{3}}$} \\
\cline { 2 - 3 } & Fiberglass Facer PIR & No Facer PIR \\
\hline 50 & $0.48 \pm 0.02$ & $0.36 \pm 0.008$ \\
\hline 70 & $0.63 \pm 0.03$ & $0.49 \pm 0.009$ \\
\hline 80 & $0.72 \pm 0.02$ & $0.55 \pm 0.009$ \\
\hline 90 & $0.94 \pm 0.01$ & $0.68 \pm 0.004$ \\
\hline 95 & $1.05 \pm 0.02$ & $0.77 \pm 0.006$ \\
\hline 100 & $11.30 \pm 0.262$ & $8.79 \pm 0.468$ \\
\hline
\end{tabular}

The water vapor permeability of PIR insulation is determined according to ASTM Standard E-96: "Standard Test Methods for Water Vapor Transmission of Materials". Using climatic chambers with wet cups and dry cups methods, the water vapor transmission rates of PIR samples are determined. The climatic chambers are set at $50 \%, 70 \%$ and $90 \%$ relative humidity and $23{ }^{\circ} \mathrm{C}$ temperature. The dry $(0 \%)$ and wet $(100 \%)$ relative humidity conditions in the test caps are provided by calcium chloride $\left(\mathrm{CaCl}_{2}\right)$ desiccant and distilled water, respectively. For each test, three circular specimens of $11.94 \mathrm{~cm}$ in diameter are used as a replica. The average water vapor permeability values of PIR boards at different mean sample relative humidity are shown in Table 5.

Table 5. Vapor permeability of PIR board.

\begin{tabular}{ccccc}
\hline \multirow{2}{*}{$\begin{array}{c}\text { Sample Mean } \\
\text { RH (\%) }\end{array}$} & $\begin{array}{c}\text { Chamber RH } \\
\mathbf{( \% )}\end{array}$ & $\begin{array}{c}\text { Cup RH } \\
\mathbf{( \% )}\end{array}$ & PIR with Fiberglass Facer & No Facer PIR \\
\cline { 4 - 5 } & 50 & 0 & $9.813 \times 10^{-13} \pm 8.897 \times 10^{-13}$ & $2.732 \times 10^{-12} \pm 1.789 \times 10^{-13}$ \\
\hline 25 & 70 & 0 & $1.110 \times 10^{-12} \pm 5.045 \times 10^{-13}$ & $2.849 \times 10^{-12} \pm 1.711 \times 10^{-13}$ \\
\hline 35 & 90 & 0 & $1.28 \times 10^{-12} \pm 1.009 \times 10^{-13}$ & $3.022 \times 10^{-12} \pm 1.786 \times 10^{-13}$ \\
\hline 45 & 50 & 100 & $1.570 \times 10^{-12} \pm 1.443 \times 10^{-13}$ & $3.223 \times 10^{-12} \pm 1.287 \times 10^{-13}$ \\
\hline 75 & 70 & 100 & $2.408 \times 10^{-12} \pm 2.418 \times 10^{-13}$ & $3.620 \times 10^{-12} \pm 1.375 \times 10^{-13}$ \\
\hline 85 & & & &
\end{tabular}

The water absorption coefficient of the PIR samples is determined according to ASTM Standard C1794: "Standard Test Methods for Determination of the Water Absorption Coefficient by Partial Immersion." Three test specimens, $100 \mathrm{~mm} \times 100 \mathrm{~mm}$ with a thickness of $37 \mathrm{~mm}$ each, are used for the measurements. The lab conditions are $33.7 \pm 0.2{ }^{\circ} \mathrm{C}$ temperature and $39.8 \pm 3 \%$ relative humidity. Water was maintained at $20.6 \pm 0.5^{\circ} \mathrm{C}$. The measured water absorption coefficients of the PIR are found to be $0.0004 \mathrm{~kg} /\left(\mathrm{m}^{2} \cdot \mathrm{s}^{1 / 2}\right)$ and $0.0007 \mathrm{~kg} /\left(\mathrm{m}^{2} \cdot \mathrm{s}^{1 / 2}\right)$ for fiberglass facer and no facer PIR boards, respectively.

The porosity of PIR samples are obtained by determining the full saturation weight of the samples following the water immersion test procedure. Based on these measurements of three replica specimens, 
the measured porosity values of no facer and fiberglass-faced of PIR boards are $31.37 \pm 1.34 \%$ and $20.51 \pm 0.39 \%$, respectively.

Since the hygrothermal property of the PIR with fiberglass is dependent on both the hygrothermal properties of PIR core and the facer material, a hygrothermal property of fiberglass-faced PIR and the PIR core is measured. By subtracting the water vapor resistance of the fiberglass-faced PIR from PIR core, the permeability of the fiberglass facer can be easily calculated. Once the independent permeability values of the facer material and PIR core are found, the overall permeability values of the fiberglass-faced PIR is computed. Figure 1 shows the water vapor transmission rate of fiberglass-faced PIR and PIR core at different thicknesses.

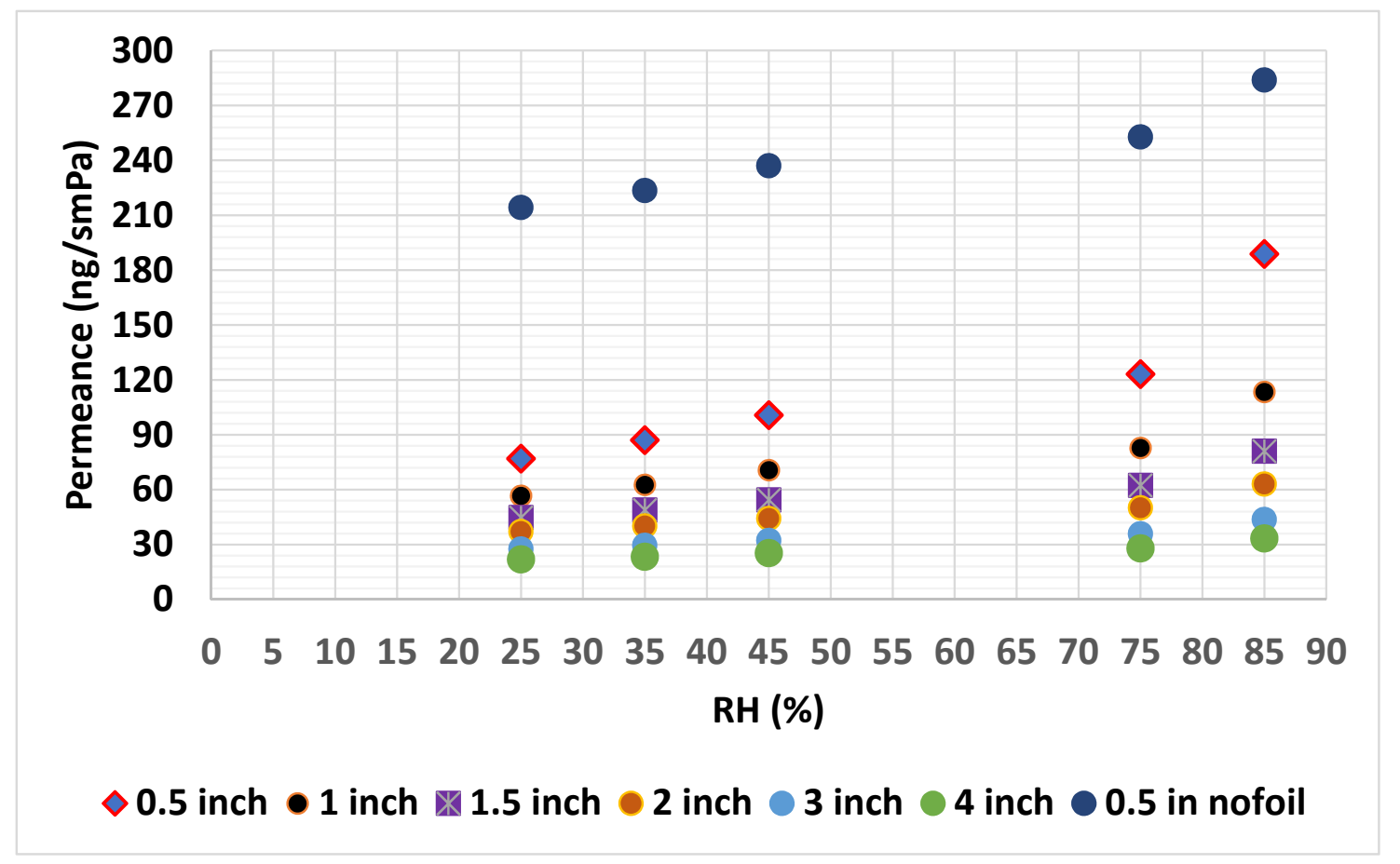

Figure 1. Water vapor permeance of fiberglass-faced Polyisocyanurate (PIR).

\section{Hygrothermal Simulation}

To study how the facing parts of rigid PIR exterior insulation affect the hygrothermal performance of a building envelope, two-year WUFI $®$ simulations for a highly insulated rainscreen wall systems are conducted. This section discusses the simulation setup, initial and boundary conditions, simulation assumptions.

\subsection{Simulation Set up}

The indoor relative humidity and temperature conditions are set based on the ASHRAE standard $160 \mathrm{P}$ Intermediate model. The input parameters varied to simulate the dynamic response of the wall system in different climates, with different types and thicknesses of exterior insulations, rain infiltration, and vapor barrier. The wall system that is considered for the study comprises the following layers of materials:

- regular Portland Stucco as an exterior cladding;

- $19 \mathrm{~mm}\left(\frac{3}{4}\right.$ in.) rainscreen air gap;

- different types and thicknesses of exterior insulations;

- spun-bonded polyolefin as a sheathing membrane (as the second plane of protection from precipitation and water intrusion); 
- $\quad$ plywood sheathing board;

- fiberglass insulation in $2 \times 6$ wood frame studs;

- $6 \mathrm{~mm}(1 / 4 \mathrm{in}$.) polyethylene sheet as a vapor and air barrier;

- gypsum board as an interior finishing layer

Table 6 shows the variation in simulation parameters during this modeling work. Three types of facing options (aluminum foil, fiberglass facer, and no facer) and two insulation thicknesses ( 2 in. and 4 in.) are considered in the study to evaluate the effect of PIR thickness and different facer materials on the overall hygrothermal performance of a wall system. Even though using a PIR product without facers is uncommon, incorporating this parameter shows how an innovative vapor-open facer product can enhance the hygrothermal performance of an envelope. While the material properties of the extruded polystyrene (XPS) were obtained from the WUFI ${ }^{\circledR}$ database, the properties for the PIR insulation with different facer material properties are measured.

Table 6. Simulation parameters.

\begin{tabular}{cc}
\hline & Parameter \\
\hline Climate & Vancouver, BC (Zone 4C) \\
& Winnipeg, MB (Zone 7) \\
\hline \multirow{2}{*}{ Exterior insulation (type) } & PIR with aluminum foil \\
PIR with fiberglass facing \\
PIR with no facing \\
Exterior insulation (thickness) & XPS \\
\hline \multirow{2}{*}{ Rain infiltration } & 2 in. \\
& 4 in. \\
& $0 \%$ \\
\end{tabular}

\subsection{Boundary and Initial Conditions}

The indoor conditions of relative humidity and temperature are set using the ASHRAE standard 160 P intermediate model. The external surface is exposed to the weather conditions of Vancouver, BC, to study the PIR performance with different facers and thickness under different moisture infiltration and combined effects of vapor barrier and exterior insulation. Weather data of two North American cities (Winnipeg, MB, Canada and Vancouver, BC, Canada) are used to study how a PIR exterior insulation of different facers performs from a hygrothermal perspective. The initial conditions of $20^{\circ} \mathrm{C}$ and $80 \% \mathrm{RH}$ are used for all wall component members and the simulation ran for two consecutive years. WUFI's weather data for cities of Winnipeg, MB, and Vancouver is used and a cold year data is selected.

\subsection{Modeling Assumptions}

Figure 2 shows the wall assembly considered in the study. Continuity of vapor/air barrier (polyethylene sheet) is assumed to be maintained in the modeling. Therefore, there is no airflow through the wall system. The PIR boards with fiberglass and aluminum facers hygrothermal properties are lumped together based on the measured values of the core and facer material. The wall system was assumed to be with no deficiency and the layers of materials to be in perfect contact, exhibiting no dimensional physical change with time. The material properties of the wall components other than the PIR boards which are used in the simulation are shown in Table 7. 


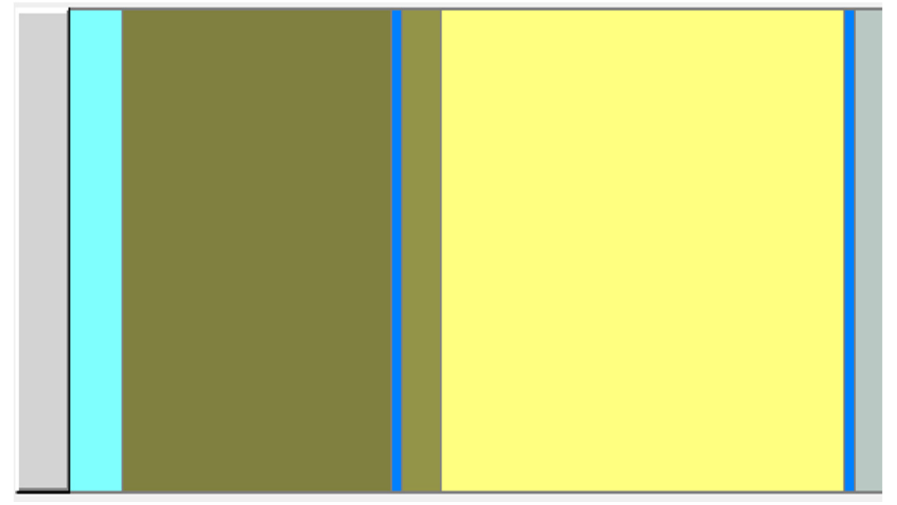

Components from left to right
1. Stucco
2. Air gap
3. Exterior insulation
4. WRB
5. Plywood
6. Fibreglass insulation
7. Vapor barrier
8. Gypsum board

Figure 2. The wall assembly.

Table 7. Material properties used for simulation.

\begin{tabular}{cccccc}
\hline Material & $\begin{array}{c}\text { Density } \\
\left(\mathbf{k g} / \mathbf{m}^{\mathbf{3}}\right)\end{array}$ & $\begin{array}{c}\text { Porosity } \\
\left(\mathbf{m}^{\mathbf{3}} \mathbf{/ \mathbf { m } ^ { 3 } )}\right.\end{array}$ & $\begin{array}{c}\text { Heat Capacity } \\
\mathbf{( J / k g K )}\end{array}$ & $\begin{array}{c}\text { Thermal } \\
\text { Conductivity } \\
\mathbf{( W / m K )}\end{array}$ & $\begin{array}{c}\text { Diffusion } \\
\text { Resistance } \\
\text { Factor } \mathbf{( - )}\end{array}$ \\
\hline $\begin{array}{c}\text { Stucco } \\
\text { XPS }\end{array}$ & 1955.5 & 0.225 & 840 & 0.399 & 355.7 \\
$\begin{array}{c}\text { Plywood } \\
\text { Spun bonded }\end{array}$ & 28.6 & 0.99 & 1470 & 0.025 & 170.56 \\
$\begin{array}{c}\text { Polyolefin } \\
\text { membrane }\end{array}$ & 470 & 0.69 & 1880 & 0.084 & 1078.2 \\
Fiberglass & 448 & 0.001 & 1500 & 2.4 & 328.4 \\
\hline
\end{tabular}

\section{Hygrothermal Simulation Results and Discussions}

In this section, based on the hygrothermal properties characterization of the PIR material, the long-term performance of a wood frame wall with PIR as exterior insulation under different thickness and facer materials for different climate zones is presented and discussed.

This section presents the results of a two-year hygrothermal assessment of four different types of exterior insulations, namely PIR with aluminum foil; PIR with fiberglass facer, PIR with no facer and XPS.

The effects of wind-driven rain, application of vapor barrier, different climates, and the overall performance of wall assemblies under different types and thicknesses of exterior insulations are presented.

\subsection{Effect of Wind-Driven Rain}

The Vancouver weather, a climate zone known for its heavy annual rainfall, is used to analyze how moisture infiltrated into an interior wall system due to wind-driven rain can affect the overall performance of a wood frame wall with exterior insulation.

Rain infiltration percentages of $0 \%, 0.1 \%$, and $0.5 \%$ are assumed to reach the sheathing board (plywood). Figures 3a, 4a and 5a show the dynamic moisture content of plywood in wall systems with two-inch exterior insulation with different rain infiltration percentages. Similarly, Figures $3 b, 4 b$ and $5 b$ represent moisture content values of plywood in wall systems with four-inch exterior insulation at $0 \%$, $0.1 \%$, and $0.5 \%$ infiltration percentages. In all cases, constant cavity ventilation of $100 \mathrm{ACH}$ is assumed. 


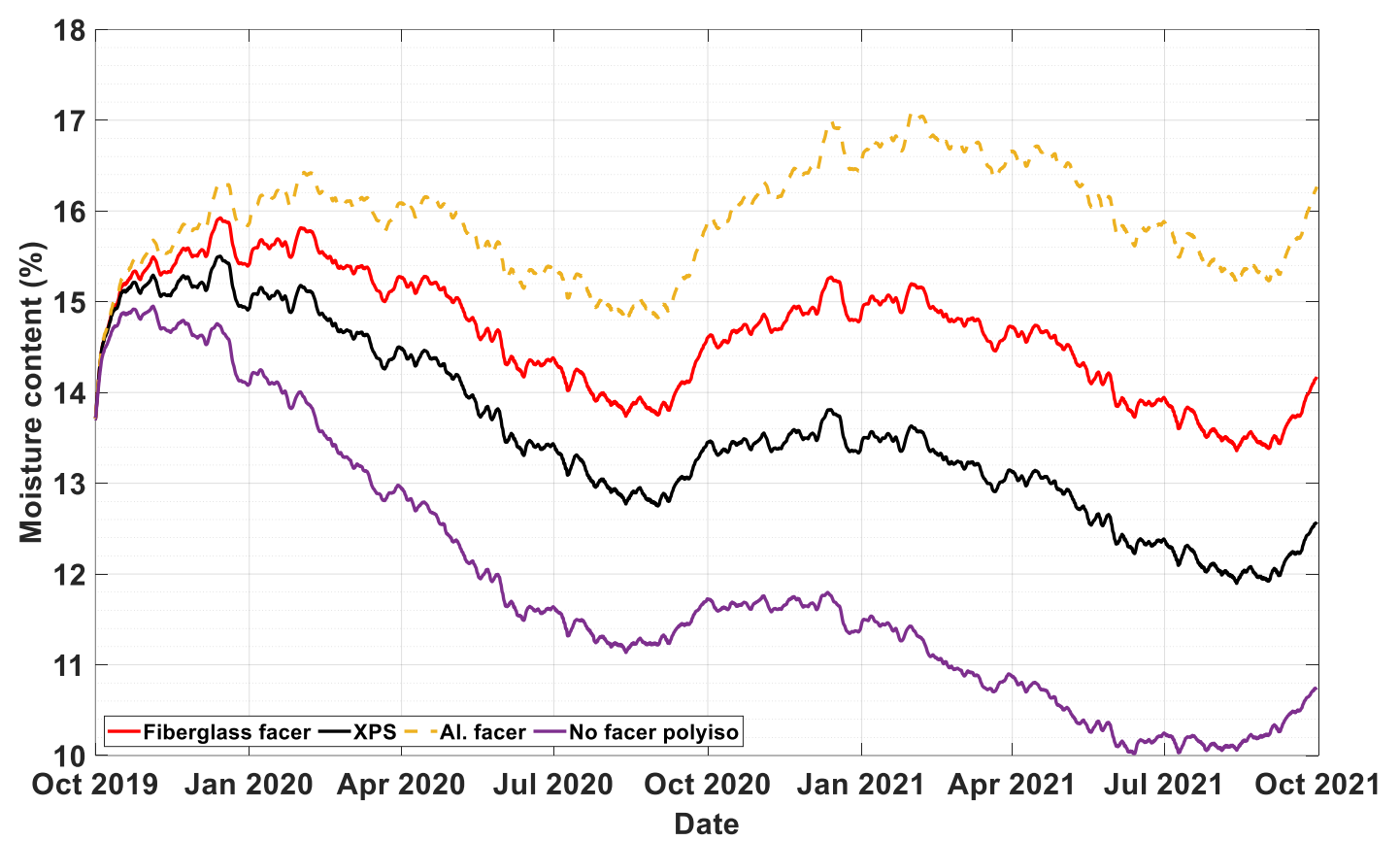

(a)

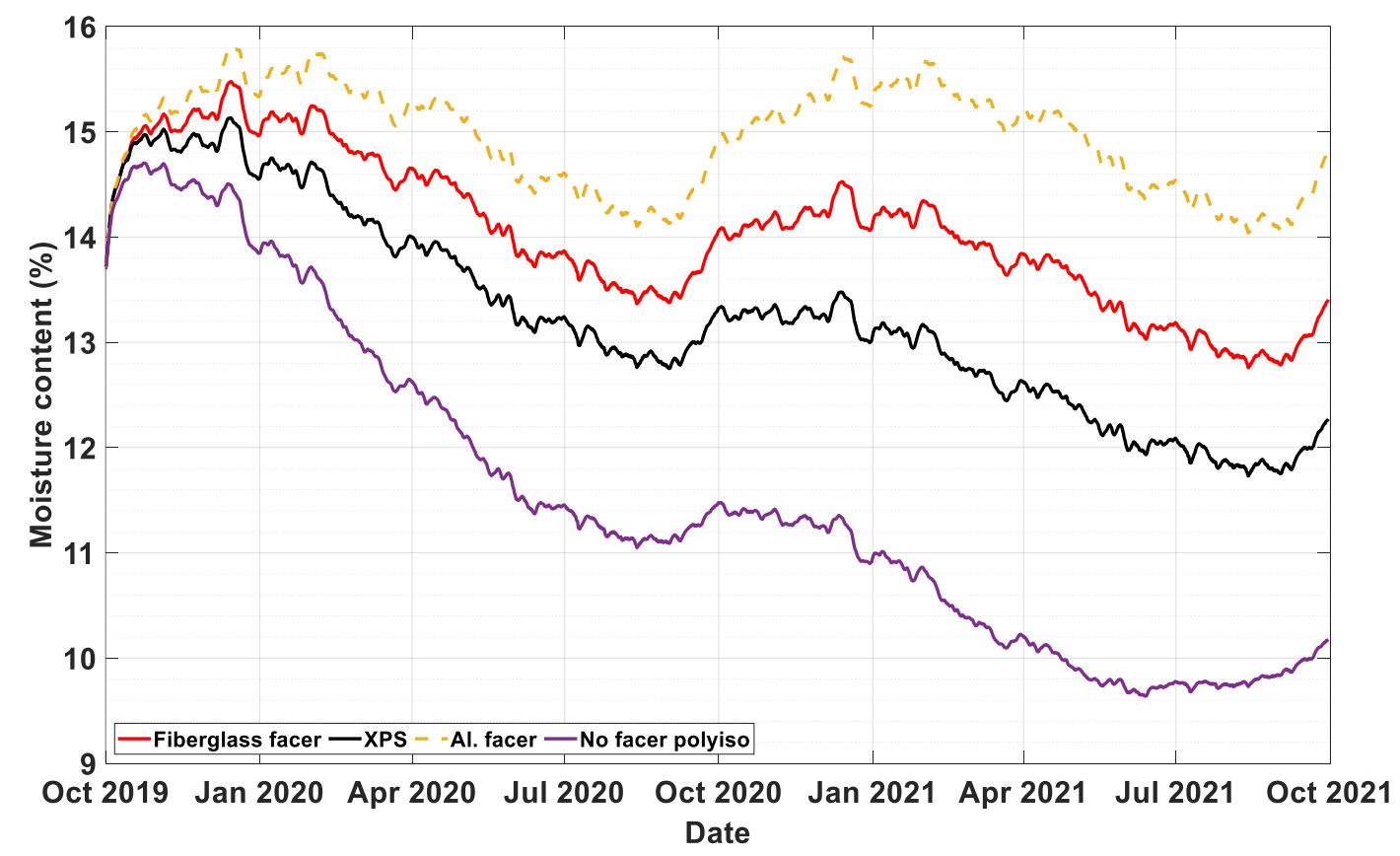

(b)

Figure 3. The moisture content of plywood with $0 \%$ rain infiltration in wall systems with (a) two-inch (b) four-inch exterior insulations. 


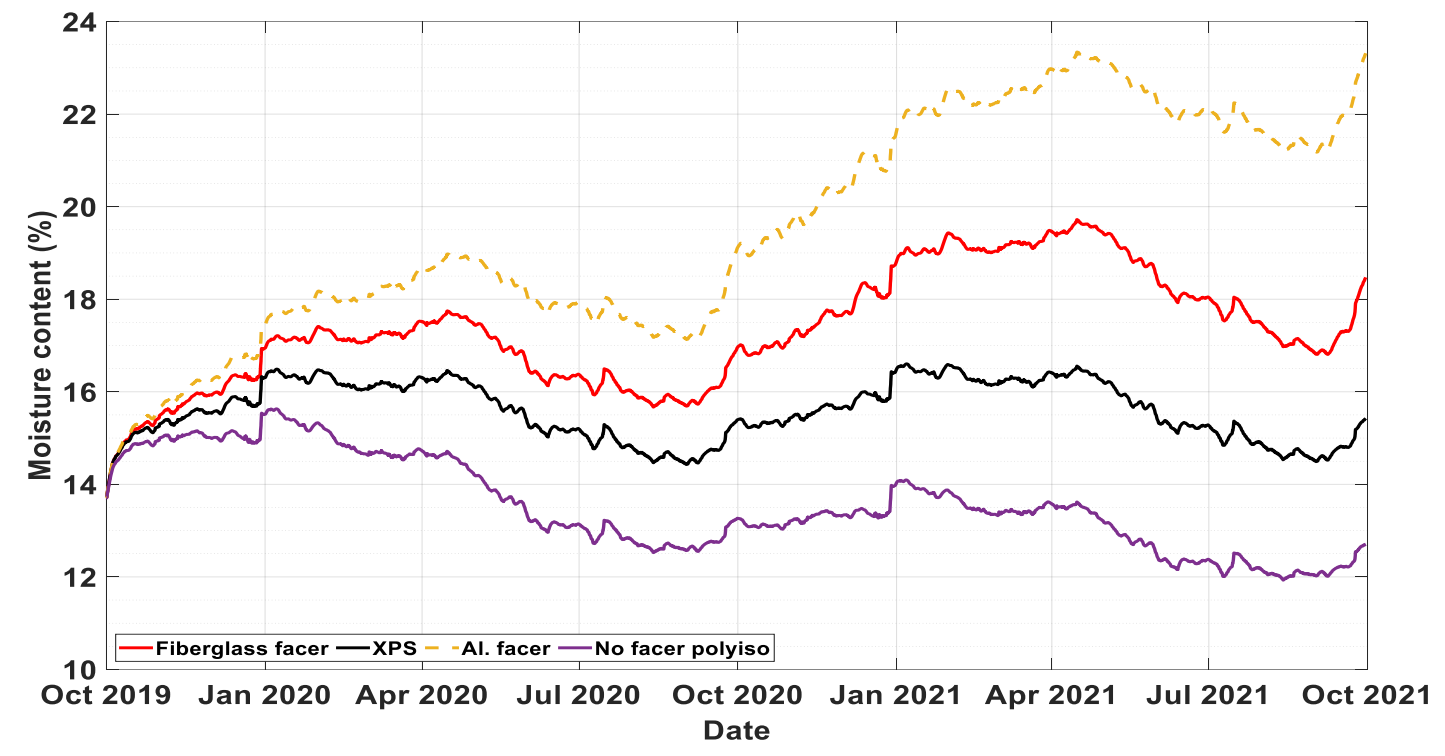

(a)

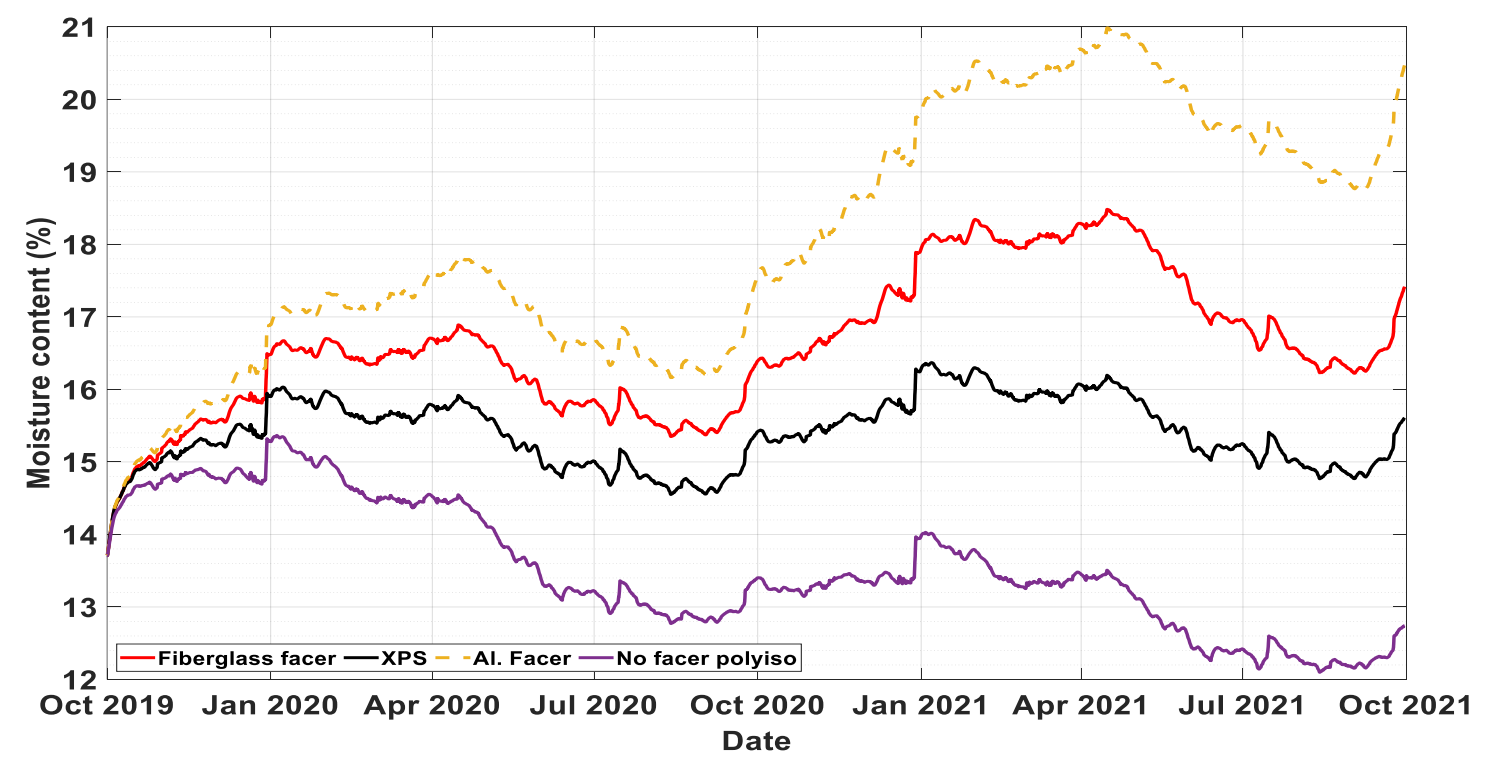

(b)

Figure 4. The moisture content of plywood with $0.1 \%$ rain infiltration in wall systems with (a) two-inch (b) four-inch exterior insulations. 


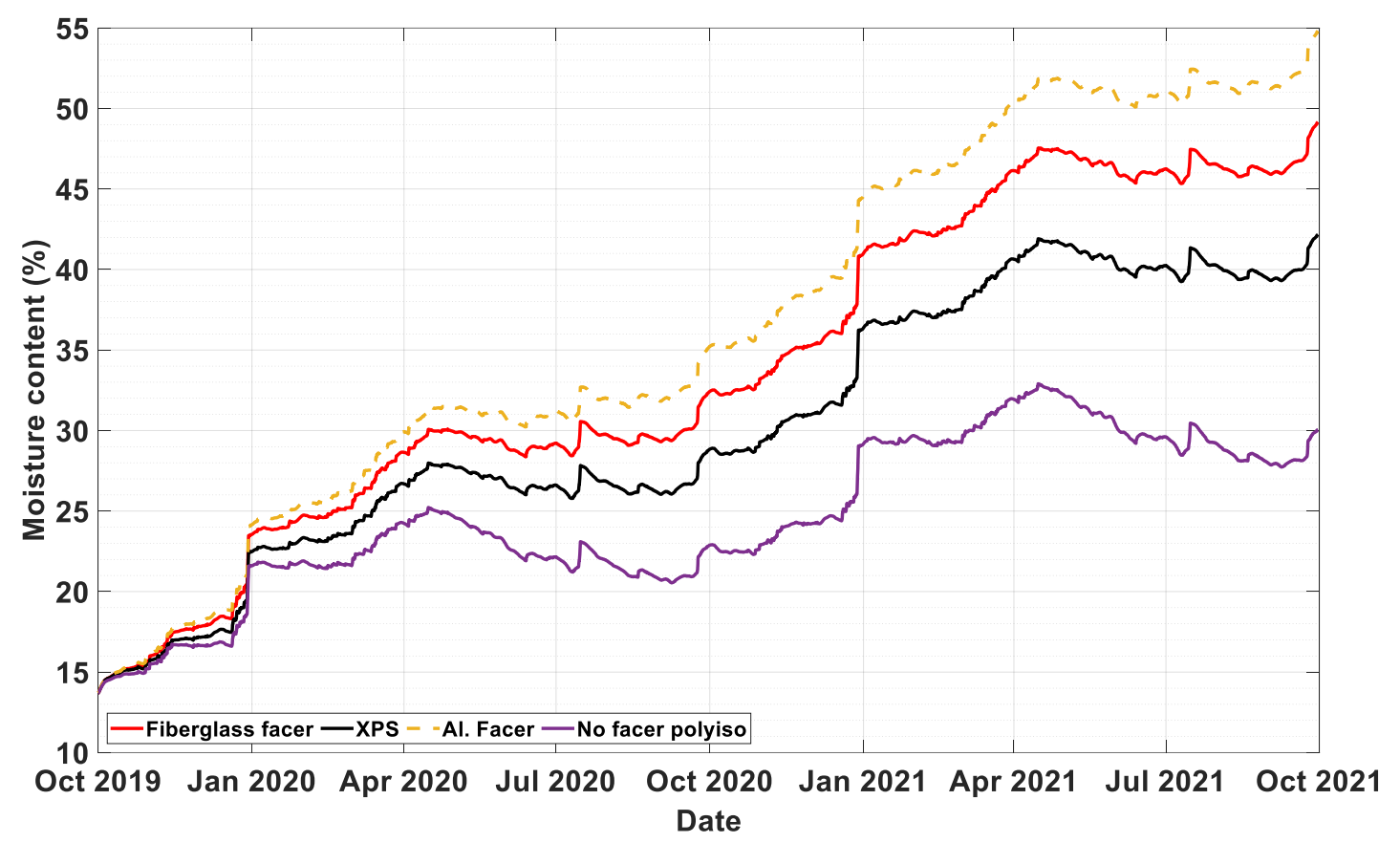

(a)

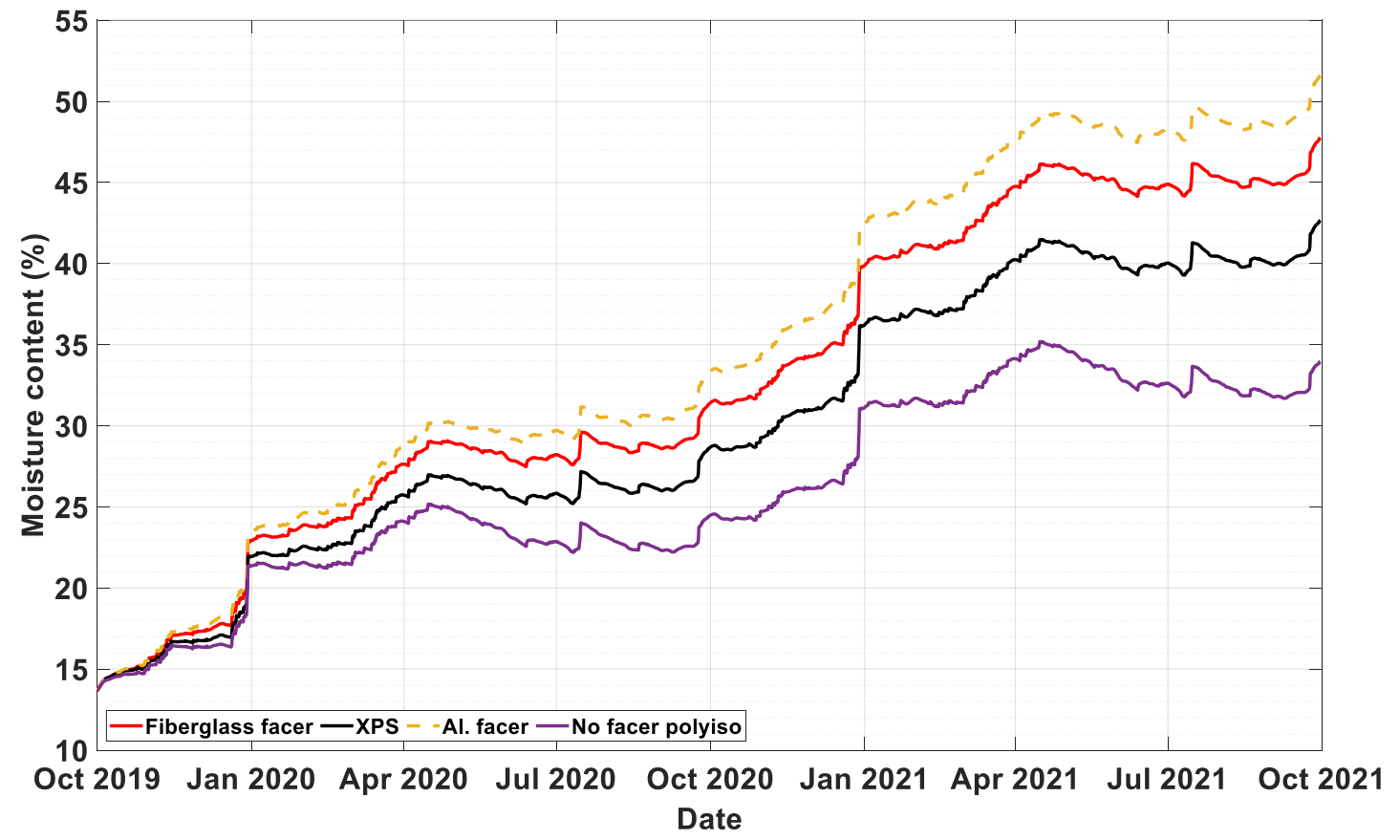

(b)

Figure 5. The moisture content of plywood with $0.5 \%$ rain infiltration in wall systems with (a) two-inch (b) four-inch exterior insulations.

In most cases, the performance ranking from the least to the most accumulation of moisture on the plywood during the simulation period was a PIR with no facer, XPS, PIR with fiberglass facer, and PIR with aluminum foil. In cases without rain infiltration, starting from the last quarter of the second year, the wall with PIR exterior insulations without facer outperformed the other walls with different exterior insulation by a bigger margin. 
In cases where the rain infiltration was not the dominant moisture source, for all wall systems and exterior insulation types, envelope systems with four-inch insulation performed better than envelope systems with two-inch insulation. This is because the thicker exterior insulation keeps the plywood warmer, minimizing the potential for condensation.

The moisture content of the plywood remained at an acceptable level for all wall systems when there is no rain infiltration. In simulation cases where $0.1 \%$ of the wind-driven rain was added in the plywood, all wall systems, except the wall with PIR with aluminum foil insulation, remained below the critical moisture level of $18 \%$, for both 2 in and 4 in continuous simulation as shown in Figure $4 a, b$, respectively. This result shows if the moisture infiltration is managed to an acceptable limit most foam insulations with the exception of vapor impermeable foam insulation can be applied.

To simulate an extreme case scenario, a rain infiltration of $0.5 \%$ is assumed. As Figure $5 a, b$ show, most of the wall systems were subjected to very high moisture accumulation in the sheathing board. In this case the moisture control performance of the wall systems has failed in both 2-in and 4-in continuous insulations of the all simulated foam boards.

\subsection{Combined Effects of Vapor Barrier and Exterior Insulation}

Many building codes require an application of a vapor barrier to be used in building envelopes to enhance the moisture durability of wall systems. This study examines if the PIR exterior insulation can serve as a vapor barrier and what are the combined effects of vapor barrier and exterior insulation in wall systems.

Figure $6 \mathrm{a}, \mathrm{b}$ show the effect of the vapor barrier on the hygrothermal performance of a wall system under different exterior insulations. Figure 6a shows when the wall includes a two-inch thick exterior insulation, the wall systems with vapor barrier performed better in all four exterior insulation cases. The walls with no vapor barrier and either exterior insulation of PIR with aluminum foil, PIR with fiberglass facing, or XPS registered a high moisture content. From the wall systems with the vapor barrier, the only wall exposed to a beyond-critical moisture content was the wall with PIR with aluminum foil insulation.

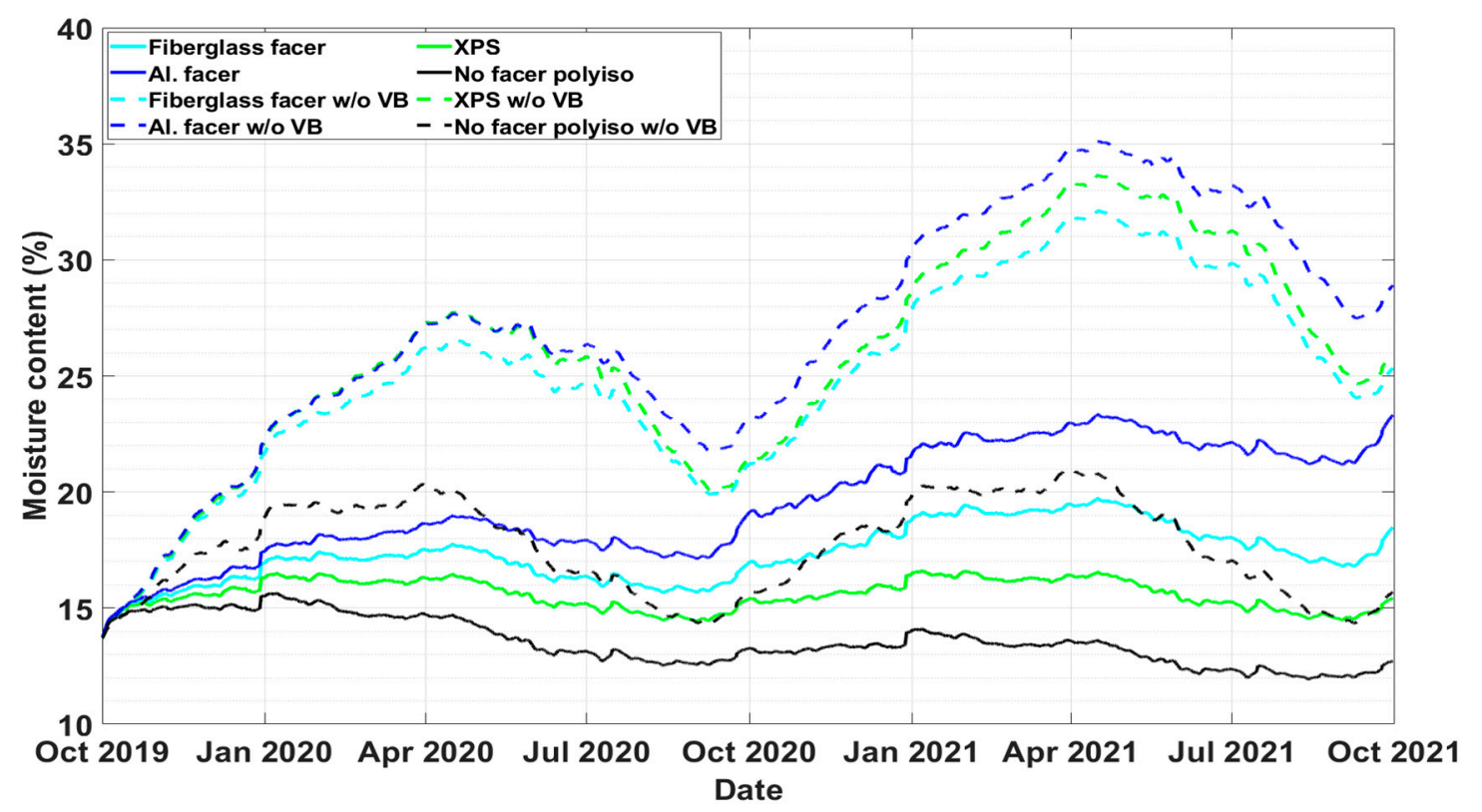

(a)

Figure 6. Cont. 


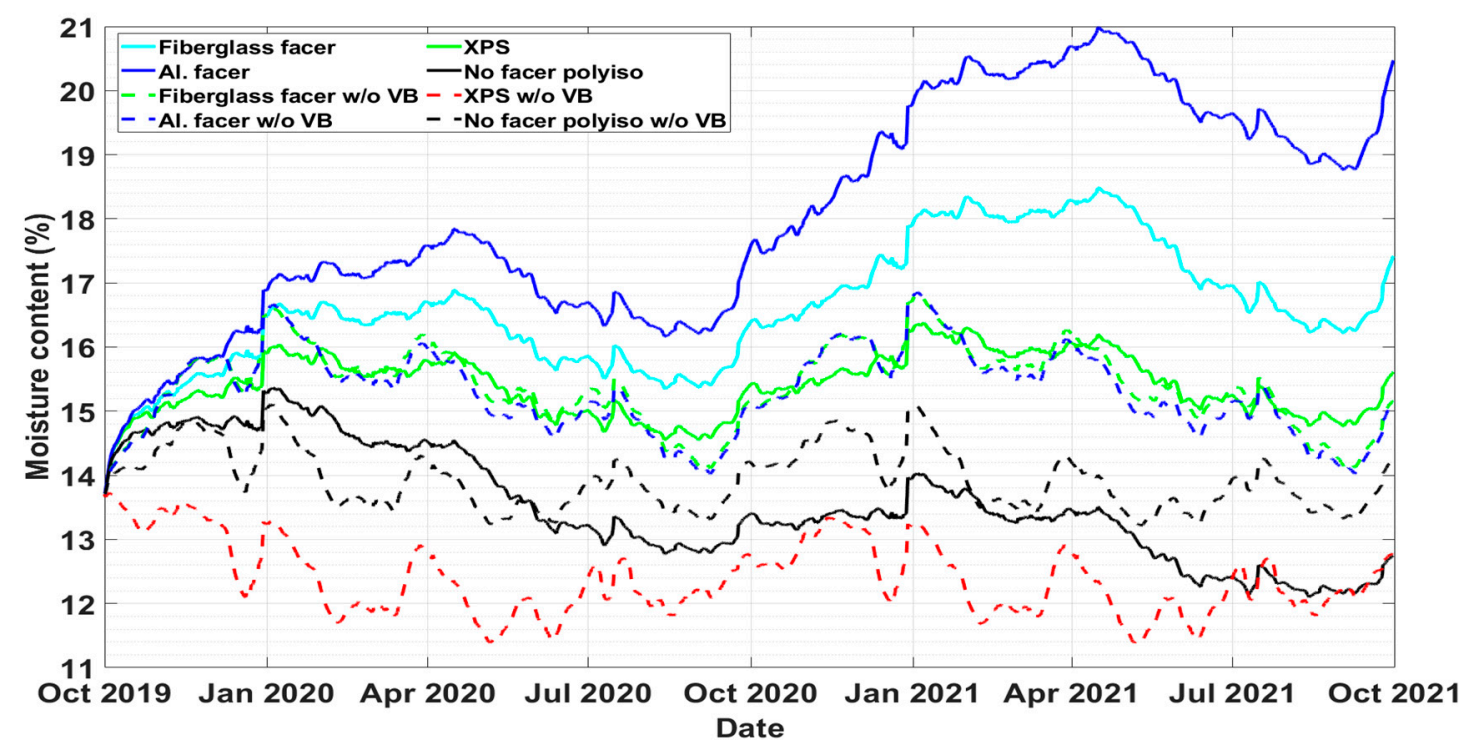

(b)

Figure 6. The moisture content of plywood in wall systems with and without vapor barrier and (a) two-inch and (b) four-inch exterior insulation thicknesses.

Figure $6 \mathrm{~b}$ shows the insulation thickness increased from two inches to four inches for all four types of exterior insulations. In all types of exterior insulations, the wall systems without vapor barrier perform better than walls with a vapor barrier. This due to the thick exterior insulation facilitating a warm condition for the plywood, discouraging condensation. The lack of a vapor barrier provides a route for moisture from rain infiltration to dry to the inside. The plywood moisture content stays below $18 \%$ in all wall systems without a vapor barrier.

\subsection{Hygrothermal Performance of Exterior Insulations under Different Climates}

This study looked at the hygrothermal performance of the exterior insulation under the different climates of the cities of Winnipeg, MB and Vancouver, BC. These locations represent wet-coastal and cold-dry climates, respectively. This simulation assumed $0.1 \%$ rain infiltration reaching the plywood surface and constant air cavity ventilation of $100 \mathrm{ACH}$. Figure $7 \mathrm{a}, \mathrm{b}$ show the moisture content of plywood for the different types of exterior insulations of two-inch and four-inch thicknesses, respectively. In all four exterior insulation cases, the plywood moisture content is lower in Winnipeg cases than those in Vancouver. This is due to Vancouver's higher annual rainfall. In both two-inch and four-inch thicknesses of PIR insulation with aluminum foil, the moisture content of the plywood exceeded 18\%. As shown in Figure 7a, the maximum moisture content of the plywood in wall systems with two-inch fiberglass-faced PIR for Winnipeg and Vancouver was $17.78 \%$ and $19.71 \%$, respectively. However, in the case of four-inch-thick fiberglass-faced PIR, the maximum moisture content of the plywood for Winnipeg and Vancouver cases was $16.70 \%$ and $18.47 \%$, respectively, as shown in Figure $7 \mathrm{~b}$. The moisture content of the plywood in all wall systems with no-facer PIR insulation remained below $15 \%$ throughout the simulation period. 


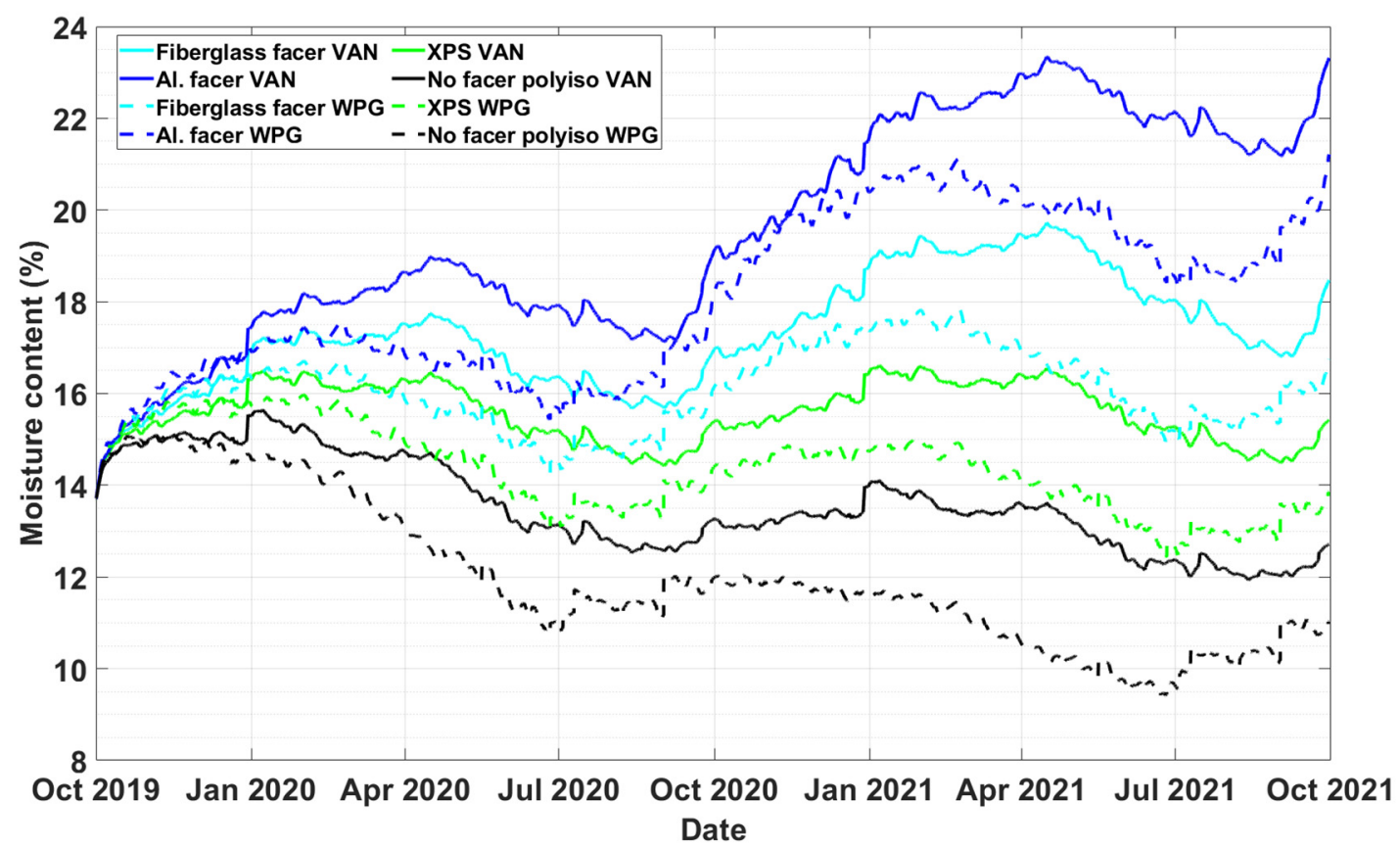

(a)

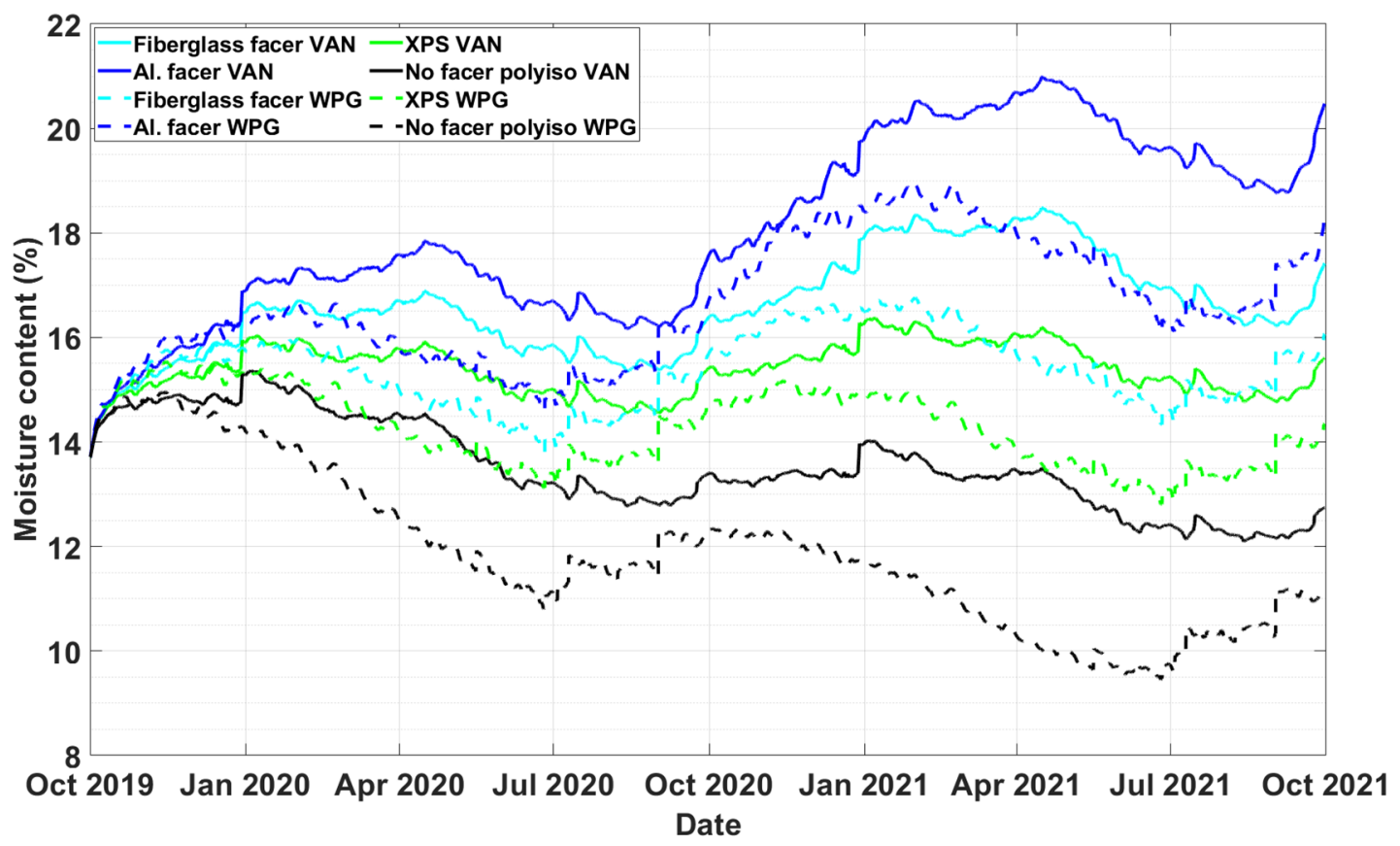

(b)

Figure 7. The moisture content of plywood in wall systems in Winnipeg, MB and Vancouver, BC with (a) two-inch and (b) four-inch exterior insulation thicknesses.

\section{Conclusions}

This study characterized the thermal and hygrothermal property of a PIR insulation with different facers. Based on the measured material property data, the long-term hygrothermal performance assessment of PIR insulation as rigid exterior insulation was examined. The experimental measurements show that most properties (such as density, water permeability and sorption isotherm) vary significantly as the thickness increases due to PIR being a composite of facer and PIR core. The material data 
presented here can be used in future modeling works to accurately simulate the hygrothermal property of PIR board with different thicknesses and facer materials.

In addition, this study examined specific application parameters such as thickness and facer types of the insulation core, simulations with varied rain infiltration rates, vapor barrier applications, and climates. Results show that thicker insulation provided a better moisture control strategy because it helped the sheathing board to stay warm. Facer materials used in the PIR insulation significantly affected the hygrothermal performance of wall systems. The hygrothermal performance of the PIR board PIR with unfaced insulation outperformed the XPS and the PIR Boards with aluminum and fiberglass facers. In light of its superior thermal performance in comparison to that of most foam insulation boards, PIR insulation with no facer or vapor-open facer material could contribute significantly to the current demands of high-performance, durable building construction practices.

Author Contributions: Conceptualization, E.I. and F.T.; Methodology, E.I. and F.T.; Software, E.I. Formal Analysis, E.I.; Investigation, E.I., W.Y.S. and F.T.; Resources, F.T.; Writing-Original Draft Preparation, E.I.; Writing-Review \& Editing, E.I. and F.T. All authors have read the manuscript and agreed to publish it.

Funding: This manuscript has been partially authored by UT-Battelle, LLC, under Contract No. DE-AC05-00OR22725 with the US Department of Energy. The authors would like to acknowledge the funding provided by NSERC Engage grants and the school of Construction and Environment at British Columbia Institute of Technology.

Conflicts of Interest: The authors declare no conflict of interest. The funders had no role in the design of the study; in the collection, analyses, or interpretation of data; in the writing of the manuscript, or in the decision to publish the results.

\section{References}

1. Ibrahim, M.; Biwole, P.H.; Wurtz, E.; Achard, P. A study on the thermal performance of exterior walls covered with a recently patented silica-aerogel-based insulating coating. Build. Environ. 2014, 81, 112-122. [CrossRef]

2. Isaia, F.; Fantucci, S.; Capozzoli, A.; Perino, M. Vacuum insulation panels: Thermal bridging effects and energy performance in real building applications. Energy Procedia 2015, 83, 269-278. [CrossRef]

3. Kossecka, E.; Kosny, J. Effect of insulation and mass distribution in exterior walls on dynamic thermal performance of whole buildings. In Proceedings of the Thermal Performance of the Exterior Envelopes of Buildings VII, Clearwater, FL, USA, 6-10 December 1998; pp. 721-731.

4. Khoukhi, M. The combined effect of heat and moisture transfer dependent thermal conductivity of polystyrene insulation material: Impact on building energy performance. Energy Build. 2018, 169, 228-235. [CrossRef]

5. Kochkin, V.; Wiehagen, J. Construction Guide to Next-Generation High-Performance Walls in Climate Zones 3-5-Part 1: $2 x 6$ Walls (No. DOE/EE-1673-1); Home Innovation Research Labs: Upper Marlboro, MD, USA, 2017.

6. Li, Y.; Dang, X.; Xia, C.; Ma, Y.; Ogura, D.; Hokoi, S. The effect of air leakage through the air cavities of building walls on mold growth risks. Energies 2020, 13, 1177. [CrossRef]

7. Ferdyn-Grygierek, J.; Kaczmarczyk, J.; Blaszczok, M.; Lubina, P.; Koper, P.; Bulińska, A. Hygrothermal risk in museum buildings located in moderate climate. Energies 2020, 13, 344. [CrossRef]

8. Ge, H.; Straube, J.; Wang, L.; Fox, M.J. Field study of hygrothermal performance of highly insulated wood-frame walls under simulated air leakage. Build. Environ. 2019, 160, 106202. [CrossRef]

9. Ibrahim, M.; Wurtz, E.; Biwole, P.H.; Achard, P.; Sallee, H. Hygrothermal performance of exterior walls covered with aerogel-based insulating rendering. Energy Build. 2014, 84, 241-251. [CrossRef]

10. Fox, M.; Straube, J.; Ge, H.; Trainor, T. Field test of hygrothermal performance of highly insulated wall assemblies. In Proceedings of the 14th Canadian Conference on Building Science and Technology, Toronto, ON, Canada, 28-30 October 2014; Volume 2830, pp. 101-110.

11. Kočí, V.; Maděra, J.; Černý, R. Exterior thermal insulation systems for AAC building envelopes: Computational analysis aimed at increasing service life. Energy Build. 2012, 47, 84-90. [CrossRef]

12. Langmans, J.; Klein, R.; Roels, S. Hygrothermal risks of using exterior air barrier systems for highly insulated light weight walls: A laboratory investigation. Build. Environ. 2012, 56, 192-202. [CrossRef]

13. Pescari, S.; Tudor, D.; Tölgyi, S.; Măduța, C. Study Concerning the Thermal Insulation Panels with Double-Side Anti-Condensation Foil on the Exterior and Polyurethane Foam or Polyisocyanurate on the Interior. Key Eng. Mater. 2015, 660, 244-248. [CrossRef] 
14. Wang, L.; Ge, H. Stochastic modelling of hygrothermal performance of highly insulated wood framed walls. Build. Environ. 2018, 146, 12-28. [CrossRef]

15. Handbook, ASHRAE: Fundamentals 2013; ASHRAE: Atlanta, GA, USA, 2013.

16. Burch, D.M.; Desjarlais, A.O. Water Vapor Measurements of Low Slope Roofing Materials; Report Submitted to National Institute of Standards and Technology: Gaithersburg, MD, USA, 1995.

17. Kosmela, P.; Hejna, A.; Suchorzewski, J.; Piszczyk, Ł.; Haponiuk, J.T. Study on the structure-property dependences of rigid pur-pir foams obtained from marine biomass-based biopolyol. Materials 2020, 13, 1257. [CrossRef]

18. Borowicz, M.; Paciorek-Sadowska, J.; Lubczak, J.; Czupryński, B. Biodegradable, flame-retardant, and bio-based rigid polyurethane/polyisocyanurate foams for thermal insulation application. Polymers 2019, 11, 1816. [CrossRef]

19. Berardi, U.; Madzarevic, J. Microstructural analysis and blowing agent concentration in aged polyurethane and polyisocyanurate foams. Appl. Therm. Eng. 2020, 164, 114440. [CrossRef]

20. Mukhopadhyaya, P.; Bomberg, M.; Kumaran, M.; Drouin, M.; Lackey, J.; Van Reenen, D.; Normandin, N. Long-term thermal resistance of polyisocyanurate foam insulation with impermeable facers. In Insulation Materials: Testing and Applications: 4th Volume; ASTM International: West Conshohocken, PA, USA, 2009.

21. Marrucho, I.M.; Santos, F.M.; Oliveira, N.; Dohrn, R. Aging of Rigid Polyurethane Foams: Thermal Conductivity of N2 and Cyclopentane Gas Mixtures. J. Cell. Plast. 2005, 41, 207-224. [CrossRef]

22. Bogdan, M.; Hoerter, J.; Moore, F.O. Meeting the insulation requirements of the building envelope with polyurethane and polyisocyanurate foam. J. Cell. Plast. 2005, 41, 41-56. [CrossRef]

23. Stovall, T. Closed Cell Foam Insulation: A Review of Long Term Thermal Performance Research; Oak Ridge National Laboratory: Oak Ridge, TN, USA, 2012.

24. Makaveckas, T.; Bliūdžius, R.; Burlingis, A. The Influence of Different Facings of Polyisocyanurate Boards on Heat Transfer through the Wall Corners of Insulated Buildings. Energies 2020, 13, 1991. [CrossRef]

25. ASTM Standard C518-17. Standard Test Method for Steady-State Thermal Transmission Properties by Means of the Heat Flow Meter Apparatus; ASTM International: West Conshohocken, PA, USA, 2017.

26. ASTM C1794-19. Standard Test Methods for Determination of the Water Absorption Coefficient by Partial Immersion; ASTM International: West Conshohocken, PA, USA, 2019.

27. ASTM C1498-04a. Standard Test Method for Hygroscopic Sorption Isotherms of Building Materials; ASTM International: West Conshohocken, PA, USA, 2016.

28. ASTM E96/E96M-16. Standard Test Methods for Water Vapor Transmission of Materials; ASTM International: West Conshohocken, PA, USA, 2016.

(C) 2020 by the authors. Licensee MDPI, Basel, Switzerland. This article is an open access article distributed under the terms and conditions of the Creative Commons Attribution (CC BY) license (http://creativecommons.org/licenses/by/4.0/). 